\title{
Description of the larva and pupa of the papaw borer weevil Pseudopiazurus papayanus (Marshall) (Coleoptera, Curculionidae, Piazurini) $)^{1}$
}

\author{
Wesley Oliveira de Sousa ${ }^{2}$, Germano H. Rosado-Neto ${ }^{2}$, Marcos A. B. Moreira² \& Paulo H. G. Zarbin ${ }^{3}$
}

\author{
${ }^{1}$ Contribution $\mathrm{n}^{\circ} 1456$ of the Departamento de Zoologia, Universidade Federal do Paraná. \\ ²Departamento de Zoologia, Universidade Federal do Paraná. Caixa Postal 19020, 81531-980 Curitiba-PR, Brasil. E-mail: wos@ufpr.br, \\ rosadoneto@ufpr.br; marcos@ufpr.br \\ ${ }^{3}$ Departamento de Química, Universidade Federal do Paraná. Caixa Postal 19081, 81531-990 Curitiba-PR, Brasil E-mail: \\ pzarbin@quimica.ufpr.br
}

\begin{abstract}
Resumo. Descrição da larva e pupa da broca do mamoeiro Pseudopiazurus papayanus (Marshall) (Coleoptera, Curculionidae, Piazurini). Larvas, pupas e adultos de Pseudopiazurus papayanus (Marshall, 1922) estão associadas com Carica papaya Linnaeus, 1753 (Caricaceae). A larva de último instar e a pupa são descritas e ilustradas. O dimorfismo sexual observado no ultimo segmento abdominal das pupas, também é ilustrado.
\end{abstract}

Palavras-chave. Curculionidae; broca do mamoeiro; formas imaturas; Piazurini.

Aвstract. Larvae, pupae and adults of the piazurine weevil Pseudopiazurus papayanus (Marshall, 1922) are associated with Carica papaya Linnaeus,1753 (Caricaceae). The larval and pupal stages are described and illustrated. The sexual differences in the last abdominal segments of the pupae are also illustrated.

KEYwORDs. Curculionidae; immature forms; papaw weevil; zygopid.

Marshall (1922) described Pseudopiazurus papayanus based on specimens collected by G. Bondar, found damaging leaf-stems of papaw (Carica papaya Linnaeus, 1753) (Caricaceae) in the State of Bahia, Brazil. Little is known about its biology. BONDAR (1948) observed that the females, during the night, make small holes in the bark where they lay the eggs; the development and growth of the larvae occur in the cortical portion of the stem; the full-grown larva makes a pupal chamber with the fibers of the papaw bark. This weevil is mentioned by Costa-lima (1956) and Silva et al. (1968) as a synonym of Pseudopiazurus obesus (Boheman, 1838). WIBMER \& O'BRIEN (1986), however, considered P. papayanus to be a valid species. Studies to evaluate this nomenclatorial change are in progress.

The purposes of this paper are to describe and illustrate in detail, larvae and pupae of P. papayanus collected on Carica papaya during February, July and October 2003 at Bahia and Rio Grande do Norte States. Larvae were reared in the laboratory until pupae were obtained. Larvae and pupae, killed in boiling water and fixed in 70\% alcohol, are deposited in the Coleção de Entomologia "Pe. J. S. Moure", Departamento de Zoologia, Universidade Federal do Paraná, Curitiba, Brazil (DZUP). The basic terminologies used in the description of the mature larvae and pupae are those of ANDERson (1947) and Burke (1968) respectively. All drawings were made by the first author using a microscope connected to a camera lucida.

\section{Pseudopiazurus papayanus (Marshall, 1922)}

Full-grown larva (Figs. 1-8). Body (Fig. 1). Robust, subcircular in cross section, moderate to strongly curved; length 10.83-12.67 mm; color cream white, except prothorax which is faintly brownish latero-dorsally; devoid of asperities.

Head (Fig. 2). Free, yellowish brown, except anterior margin of frons and mandibles, which are darker brown; clypeus and labrum brown only at base; head capsule (Fig. 2) approximately as long as broad, $2.50-2.83 \mathrm{~mm}$ of width. Anterior ocellus represented by a small pigmented spot, without a convex lens; posterior ocellus absent. Antenna (Fig. 7) consisting of one membranous article which bears a conical accessory appendage and four smaller processes situated on basal article. Catapophyses distinct and in same plane as frons. Hypopharyngeal bracon membranous, readily discernible. Epicranial suture narrow, approximately half as long as head capsule. Frontal suture incomplete. Endocarinal line distinct, nearly half as long as frons. Epicranium with five pairs of dorsal setae, long and subequal, except setae 4 which is little shorter; two pairs of similiar and long lateral setae, subequal; and two pairs of very short ventral setae. Frons bearing five pairs of setae, seta 1 the shortest, seta 2 moderately long, seta 3 longer than seta 2 and subequal to seta 5 ; setae 4 slightly longer than seta 5. Clypeus (Fig. 4) wider than long, with two pairs of short and similar setae; a pair of sensilla located at the side of clypeal seta 1; anterior margin very weakly emarginate. Labrum (Fig. 4) bearing three pairs of setae, subequal; anterior margin with a well distinct median lobe. Epipharynx (Fig. 5) bearing three pairs of anterolateral setae, one pair of them very short; two pairs of median spines and one pair of epipharyngeal sensilla situated at the external side of the anterior pair of median spines; labral rods elongated, converging and fused posteriorly. Mandible (Fig. 8) stout, triangular-shaped, strongly sclerotized, 

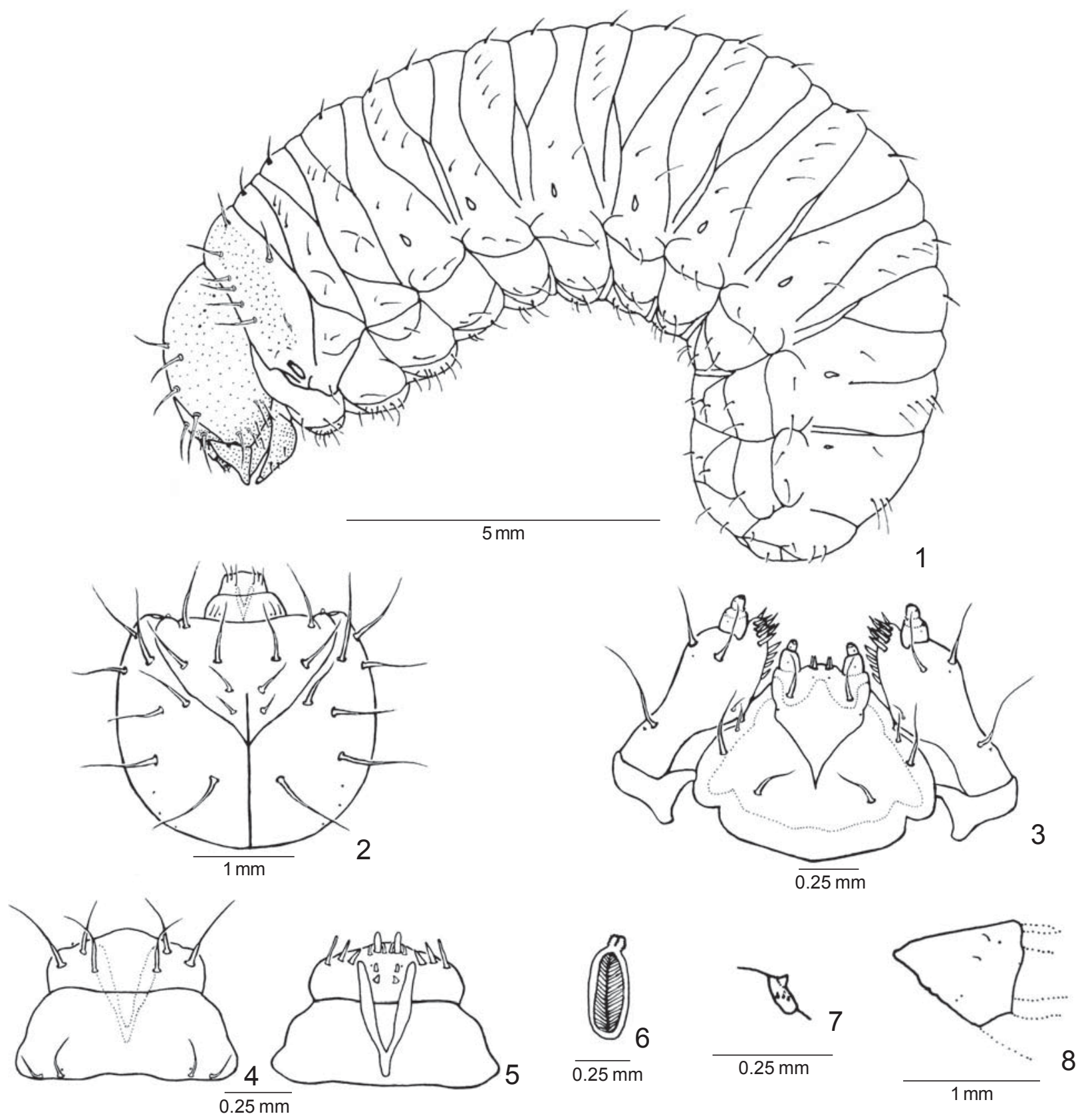

Figs. 1-8. Pseudopiazurus papayanus: 1, larva, lateral view; 2, head capsule, mouthparts removed, dorsal view; 3, labium and maxillae, ventral view; 4, clypeus and labrum, dorsal view; 5, epipharynx; 6, thoracic spiracle; 7, right antenna; 8 , right mandible, dorsal view.

with one apical tooth and two obtuse mesal teeth; dorsally bearing two minute mandibular setae and a sensillum, ventrally two sensilla. Maxillary palpus (Fig. 3) with two articles; basal article thicker than apical one, with two sensilla and a minute lateral seta; apical article bearing one sensillum and an apical cluster of papillae; stipes with four setae on ventral surface, stipital seta 2 much shorter than seta 1,3 and 4; two sensilla, one near seta 1 and other near seta 4 ; mala with eleven setae arranged in a row, being seven dorsal setae and four ventral setae. Labial palpus (Fig. 3) with two articles; basal article thick, with one sensillum; apical article with one sensillum and an apical cluster of papillae. Prementum bearing one pair of long setae and one pair of sensilla; glossa with two pairs of short setae and a pair of sensilla; premental sclerite with a very acute posterior projection; postmentum with three pairs of setae; seta 2 distinctly longer than seta 1 and 3; postmental seta 3 shorter.

Thorax (Fig. 1). Pronotum with a slightly sclerotized plate, brownish; with eleven setae (setae described on one side of body only) of which five long setae situated on anterior margin near head, two long setae posteriorly and four short setae near thoracic spiracle, being one very minute. Spiracle bicameral 

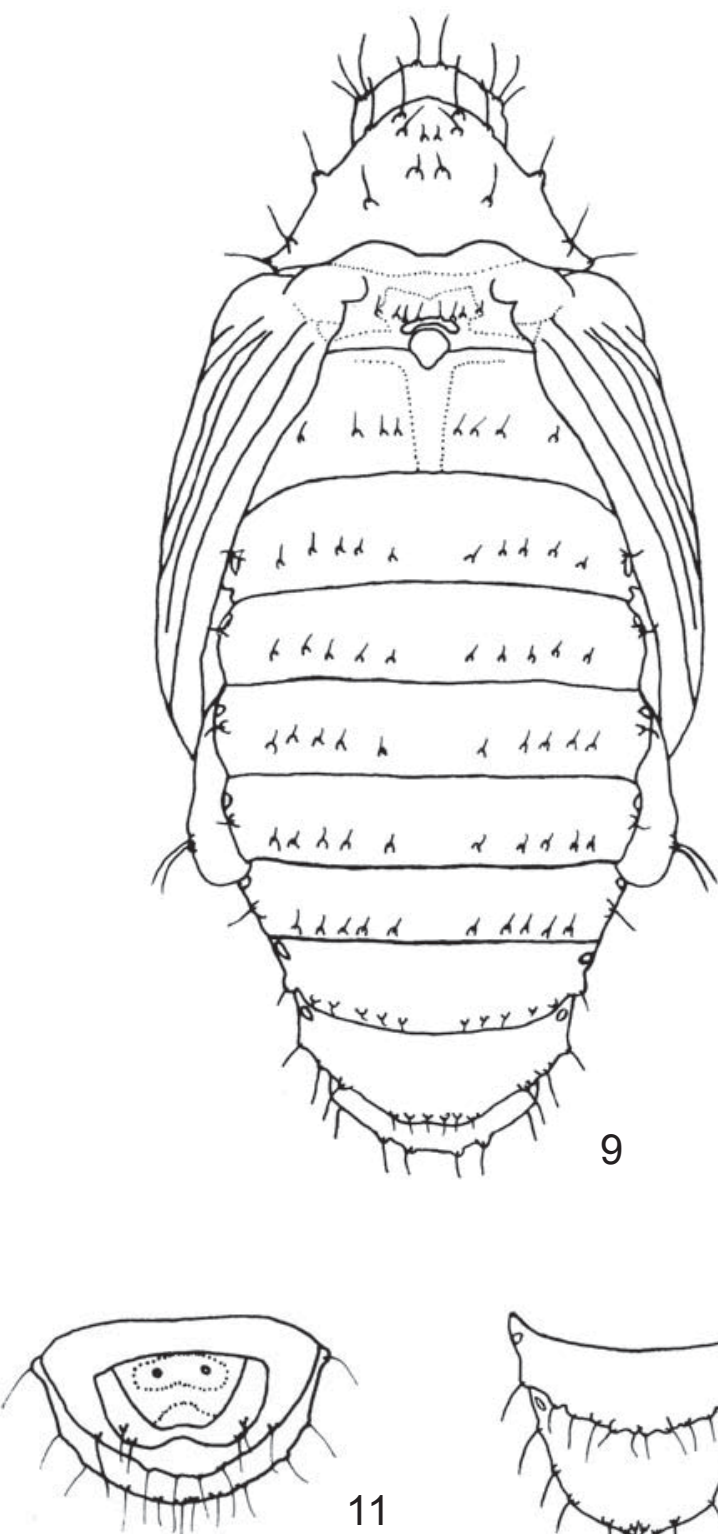

11

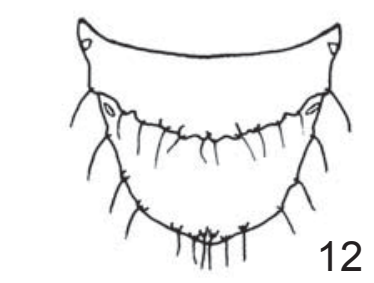

$\overline{1 \mathrm{~mm}}$
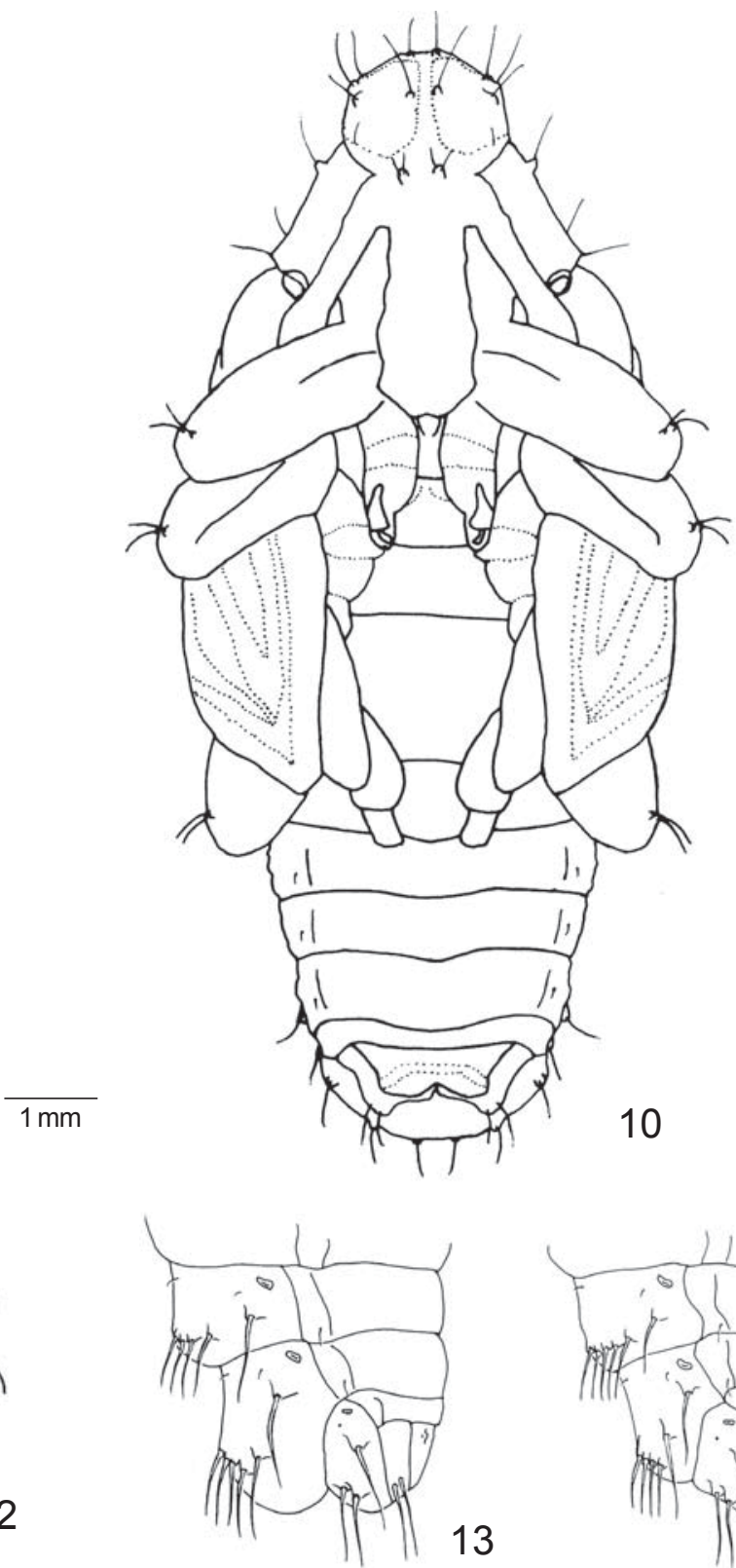

13

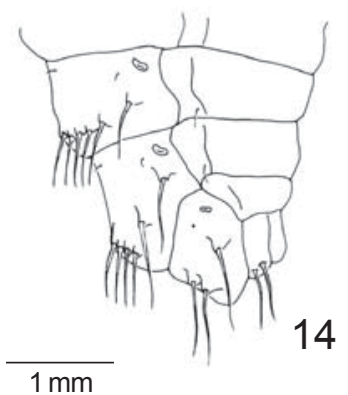

Figs. 9-14. Pseudopiazurus papyanus: 9, pupa male, dorsal view; 10, pupa male, ventral view; 11, segments 8 and 9 of female, ventral view; 12, segments 6 and 7 ( 8 not visible) of female, dorsal view; 13, segments 7, 8 and 9 of female, lateral view; 14, segments 7, 8 and 9 of male, lateral view.

(Fig. 6), peritreme subeliptic, air tubes annulated and very short. Prodorsum of meso- and metathorax each with one long seta. Posdorsal area of meso- and metathorax each bearing four setae, seta 3 and 4 twice or more the length of setae 1 and 2 . Alar area of meso- and metahorax with one seta, frequently minute. Spiracular area of meso- and metathorax each bearing one long seta and one very minute seta. Mesothorax and metathorax each with one epipleural seta. Prothorax with two long pleural setae; meso- and metathorax each with one long pleural seta. Pedal area of each thoracic segment bearing seven setae, being 2 long setae and 5 shorter setae. Sternum of each thoracic segment with one moderately long seta on each side of the midventral line.

Abdomen (Fig. 1). Eight pairs of bicameral spiracles smaller than prothoracic spiracle but with the same shape. First seven abdominal segments each with three dorsal folds (folds II, III and IV); two dorsal folds on segment 8 ; folds not distinct on segment 9. Lateral fold (fold I) developed on segments 2-8, narrow, without setae, sometimes very reduced and not clearly distinct on segment 8 . Segments 1 through 7 each on each side bears the following setae: one long prodorsal seta; five postdorsal setae, setae 3 and 5 longer than setae 1, 2 and 4, 
seta 4 the shortest; two setae on spiracular area, seta 1 minute, seta 2 long; two setae on epipleurum, seta 1 shorter than seta 2; two setae on pleurum, seta 1 much shorter than seta 2; one long seta on pedal area; and two setae moderately long on the eusternum. Sternellum present, devoid of setae. Abdominal segment 8 bearing a minute seta above the spiracle and three dorsal setae, seta 2 and 3 subequal and longer than seta 1 ; the setae on the other areas as in the segments 1-7. Abdominal segment 9 on each side bearing six setae, being 2 long dorsal setae, one lateral minute seta and 3 latero-ventrally short setae. Anus terminal, surrounded by four lobes; the lateral lobe on each side with one short seta.

Material examined. BRAZIL. Bahia: Cruz das Almas, 10 larvae, 2528.II.2003, Marilene Fancelli col. (DZUP). Rio Grande do Norte: Touros, 11 larvae, 05.X.2003, Marcos Moreira col. (DZUP).

Pupa (Figs. 9-14). Body (Figs. 9 and 10). Elongate; length 10;83-13.67 mm; color cream white, except for eyes, which are pale to dark.

Head. Rostrum moderately long, reaching the mesocoxae; with one pair of short and delicate epistomal setae located at the apex; distirostral setae absent; two or sometimes three pairs of basirostral setae born on summit of the same protuberance. Eyes case bearing one pair of setae near to the interorobital area and three pairs of setae near to the posterior orbital; one pair of frontal setae; and also one pair of minute sessile lateral setae which may be absent. All setae, except epistomal pair of rostrum and the lateral pair below the eyes are moderately long, straight or rather curved in the tip, and borne on apex of subconical or round tubercle.

Prothorax. Prothoracic depression absent; spiracle well developed and clearly visible laterally; bearing one pair of anteromedian setae; two pairs of anterolateral setae; two pairs of median setae; one pair of posteromedian setae; and three pairs of posterolateral setae. All prothoracic setae subequal in lenght and size to those of head and rostrum, and associated with small conical or round tubercles. The median setae and its associate tubercles located in a larger median pronotal protuberance.

Mesothorax. One pair of minute anteronotal setae, not clearly distinct and frequently absent; four pairs of mesonotal setae slightly shorter than those of prothorax; mesonotal setae 1 and 2 sessile, delicate and shorter than mesonotal setae 3 and 4 , sometimes the mesonotal setae 2 the shortest; all setae arranged in transverse row and only mesonotal setae 3 and 4 arising from slight prominence.

Metathorax. Anteronotal setae lacking; with four pairs of metanotal setae like those of mesothorax; arranged also in transverse row and setae more widely separated, especially metanotal setae 4 .

Legs. Femora each bearing one pair of long preapical setae; each setae borne on small round tubercle.

Abdomen. Nine segments distinct, but only 8 in male and 7 segments in female visible dorsally; anterotergal setae minute, not distinct, sessile; segments $1-7$ bearing five pairs of discotergal setae borne on summit of subconical tubercle; two pairs of laterotergal setae just above spiracles, laterotergal setae 1 minute, sessile and sometimes not distinct or lacking, laterotergal setae 2 long and associated with small round or subconical protuberance; one pair of an inconspicuous laterosternal setae, sometimes short and distinct in one or other segment, or minute and quite not visible or absent. Segment 8 with two pairs of discotergal setae and one pair of laterotergal setae; the setae associated with small tubercle. Segment 9 with one pair of setae borne lateroventrally on each side of each apical process.

Sexual dimorphism. Dorsally, male with eight segments visible (Fig. 9); tergum 7 with one short slope behind the discotergal setae (Fig. 14). Female with tergum 7 with one long slope, frequently more extended backwards after discotergal setae, reaching apex of tergum 8 (Fig. 13); this not seen in dorsal view (Fig. 12). Female with small round convexity located on each side of sternum 9 (Fig. 11); convexity absent in male (Fig. 10).

Material examined. BRAZIL. Bahia: Cruz das Almas, 5 pupae (2 females, 3 males), 25-28.II.2003, Marilene Fancelli col. (DZUP). Rio Grande do Norte: Touros, 7 pupae (4 females, 3 males), 04.VII.2003, Marcos Moreira col. (DZUP).

Acknowledgments. We are indebted to Marilene Fancelli (Embrapa Mandioca e Fruticultura, Cruz das Almas, Bahia) who provided the studied material and to Luís A. Foerster (Universidade Federal do Paraná) for revising and improvement of the manuscript.

\section{REFERENCES}

Anderson, W. H. 1947. A terminology for the anatomical characters useful in the taxonomy of weevil larvae. Proceedings of the Entomological Society of Washington 49(5): 123-132.

Bondar, G. 1948. Broca do mamoeiro (Pseudopiazurus papayanus Mshl). Boletim do Campo 23: 1-2.

Burke, H. 1968. Pupae of the weevil tribe Anthonomini (Coleoptera: Curculionidae). The Texas Agricultural Experiment Station. Technical Monographs 5: 1-92.

Costa-Lima, A. [M.] DA. 1956. Insetos do Brasil. Coleópteros. Rio de Janeiro, Escola Nacional de Agronomia, vol. 10, 373 p.

Marshall, G. A. K. 1922. Some injurious Neotropical weevils (Curculionidae). Bulletin of Entomological Research 13(1): 5971.

Silva, A. G. D’A.; C. R. Gonçalves; D. M. Galvão; A. J. L. Gonçalves; J. Gomes; M. Do N. Silva \& L. DE Simon I. 1968. Quarto catálogo dos insetos que vivem nas plantas do Brasil. Seus parasitos e predadores. Insetos hospedeiros e inimigos naturais. Rio de Janeiro, Ministério da Agricultura, vol. 1, parte 2, 622 p.

WibMeR, G. J. \& C. W. O'BRIEN. 1986. Annotated checklist of the weevils (Curculionidae sensu lato) of South America (Coleoptera: Curculionoidea). Memoirs of the American Entomological Institute (39): xvi $+563 \mathrm{p}$.

Received 24.X.2003; accepted 30.IV.2004 